\title{
Mineralogical Properties of Cracking Clay Soils along Toposequence at Middle and Lower Clay Plains of Eastern Nuba Mountains South Kordofan, Sudan
}

\author{
El-Abbas Doka M. Ali ${ }^{1}$, Omima Omer A. Showgi ${ }^{2}$, \\ El Tag Fadlalla A. Rahim ${ }^{3}$ and Mahgoub Suliman Mohamedain ${ }^{4 *}$ \\ ${ }^{1}$ Land Evaluation and Remote Sensing, College of Agricultural Studies, Sudan University of \\ Science and Technology, Shambat \\ ${ }^{2}$ Properties and Genesis of Soils, College of Science and Technology, Department of Botany, \\ Shendi University, Nile State, Showgi \\ ${ }^{3}$ Soil Pedology, Department of Soil Science and Environmental, Faculty of Agriculture, \\ University of Khartoum, Shambat - Khartoum North, Sudan \\ ${ }^{4}$ Remote Sensing for Forest Management, College of Forestry and Range Science, Sudan \\ University of Science and Technology \\ *Corresponding author
}

\section{Keywords \\ Nuba Mountains, Middle and Lower Clay Plains, Clay Mineralogy.}

\section{Article Info}

Accepted:

28 August 2016 Available Online: 10 October 2016

\section{A B S T R A C T}

This research study was carried to identify the mineralogical properties of the cracking clay soils (Vertisols) at the upper clay plains located at the eastern parts of Nuba Mountains, Sudan. Soil samples were collected from profile pits along a toposequence in a transect stretching from Abbasyia to Megenis through Terter $(64 \mathrm{Km})$.Another lowest site was selecte on the White Nile terrace adjacent to lower clay plain to investigate its clay mineralogy in relation to Nuba Mountains clays. The area is an intermountain, slightly undulating clay plain surrounded by the Nuba mountains and hills. The majority of the soils identified belong to the dark cracking clays (Ahmed, N. 1996). The huge mantle of clay rests on the basement complex but the origin of this clay is somewhat controversial, it is either transported from another place and deposited were it is or formed in situ (Vail, J.R. 1971). According to (Balwant, S. and H. Susan. 2002), clay minerals particularly smectite are sensitive to pressure and temperature conditions and to variations in the chemical environment (sensitivity is expressed as crystallographic and mineralogical changes). Consequently, the study of clays can supply a great deal of information concerning the processes that occur in the evolution of the sequences of which they form a part such as weathering, hydrothermal alteration, digenesis, low grade metamorphism, etc. Furthermore, clay may reflect the history of the sediments better than any other component, because the characteristics of the clay minerals are to some extent subject to changes depending on the environment in which they are found (Grim 1968). The x- ray diffraction (XRD) analyses were used to identify quantitatively and semi-quantitatively the proportion of each clay mineral with respect to other clay minerals present in the tested samples. The X - Ray diffraction analyses of samples in these profiles indicates that the dominant clay minerals is Smectite with percentages ranging between $71.3-36.1 \%$ followed by kaolinite $46.5-22.2 \%$, chlorite $6.8-1.2 \%$, illite $15.32-2.6 \%$ and Semctitel Chlorite $6.9-1.0 \%$. The bulk mineral analysis indicate the present quartz minerals found in all sites with percentages $69.2,12.5,35.1,86.8,31.7,31.6,50.1,50.6$; mica is found only in profiles except siteTE008with percentages of 16.9 and traces at TE005;Kaolinite present in sitesTE009, Te008, TE006, TE004 and ME003 with percentage of 8.9, 1.9, 2.1, traces, 0.6, 0.4; Vermiculite is found only in site TE009 with percentages of 5.6 and non-silicate minerals Magnetite exists in sites TE009, TE008, TE007 with percentages of 2.5, traces and 11.7 and Clinochlopreexist in TE007 and TE005 with percentages of 28.4 and 40.7. In aggregates this mineralogical assemblages occurring in three areas (Abbasyia,Megenis and Terter) suggest origins of parent materials derived from basic igneous \metamorphic rocks that have under gone weathering and in situ formation of clay minerals that have imposed magnitude of variations in the Pedological features. 


\section{Introduction}

In the Sudan, Vertisols occur on large tract of land, totaling perhaps 50 million ha in area, is divided naturally into four separated areas: the central clay plain (Gezira), the eastern clay plain (El Gadarif), the Nuba Mountains region and the southern clay plain (Abyei-Bahr Al Arab). Vertisol in the Nuba Mountains region occur on gently undulating plains and have better surface drained than those in extremely flat landscape of the other three clay plains. Dark cracking clay soils "Vertisols" cover not only large areas of the low lying plains but also they occur on undulating higher plains and in many intermountain valleys throughout the Nuba Mountains area. Some of these clays, notably those in eastern and southern lower clay plains, Khor Abu Habil, Wadi Al Ghalla and the clays of Bahr el Arab valley, can only be alluvial. But some other clay, for instance, on undulating high plains in the Nuba Mountains uplands area indicate a non-alluvial origin.

The Nuba Mountains Vertisols are considered to be derived from the underlying bedrock. Therefore, it is expected that the parent materials at upper clay plains have undergone through a shorter pedogenetic processes compared to those on low alluvial plains. These non-alluvial clays are thought to be moved slowly down slope by combined process of wash and mass movement. Bases are thought to be washed from higher areas to accumulate on the plains where they help in the formation of the higher base status clays. These soils are plastic, sticky and have moderately high to high cation exchange capacities and a high capacity to shrink and swell with changes in moisture. Because the lower horizons are subject to pressure when the soils swell, they are compact and very slowly permeable to water. They are usually neutral to slightly in reaction (Pacheco and Dawoud, 1976).
This research study attempts to identify the mineralogical properties of the Vertisols at Middle and Lower clay plains at Nuba Mountains which gives information about soil forming processes, alterations, and development of the soil. Many research studies were carried to characterize the clay minerals of Vertisols at different parts the alluvial lowland clay plains of Sudan which are mainly used for irrigated farming. The rainfed lands found less detailed research attention and particularly the upper, middle and lower clay plains at Nuba Mountains region which need more understanding of their formation and behavior as related to their use and management. Since the Vertisols in Nuba Mountains region occur in topographic sequence of plains (upper, middle and lower plains); then the mineralogical characterization provided by this study will lay the bases for the subsequent research efforts to study these soils.

\section{The Study Area}

The study area is located in the eastern part of the Nuba Mountains in South Kordofan State. The sampling transect $(65 \mathrm{Km})$, starts from Al Abbasyia town (height $561 \mathrm{~m} \mathrm{ASL}$ ) in the northeast and ending towards southeast at Megenis (height 406m ASL), Figure1 and Figure 2. The study area has tropical semi - arid zone of summer rain. The rainfall is comparatively high as the survey area lies within isohyets $600-800$ $\mathrm{mm}$. The amount of rainfall increases from northeast to southwest (Table 1). The rainy season starts from late June and extends to early October month. Maximum temperatures range between $31 \mathrm{C}^{\circ}$ and $40 \mathrm{C}^{\circ}$ with March to May as the hottest months and monthly minimum temperatures range between $17 \mathrm{C}^{\mathrm{o}}$ and 24 (Abbasyia) $\mathrm{C}^{\mathrm{O}}$ coldest months being from early December to the end February. In Habila, relative humidity is 
$70 \%$ in July - August and falls to $20-25 \%$ during winter (ELtom, 1972 and Dawoud, 1974).

\section{Materials and Methods}

Transect along the toposequence stretches in eastward direction from Al Abbasyia to Megenis. The area under study is situated between longitudes $31^{\circ} 00^{\prime \prime}$ and $32^{\circ} 35^{\prime \prime}$ East and latitudes $11^{\circ} 56^{\prime \prime}$ and $12^{\circ} 09^{\prime \prime}$ north. Eight soil samples were collected from eight sites shown in Table 2 and represented in Figure 2. Sub-scenes of Landsat TM Satellite image 2010 covering the study area were used for locating the sampling sites. The elevation of the study sites ranges between 561 and 381 m ASL (Figure 3).

A pit of about $1 \times 2 \mathrm{~m}$ in length with $1.5 \mathrm{~m}$ depth was dug for sampling at each site. The face of the pit to be used for observation, photographing and sampling should face the sun. Notes on morphology, horizons sequence and soil classification were recorded following the standard procedures. Soil samples, one from each soil profile/ sample site (Table 2) were selected for identification of clay mineralogy by $x$-ray diffraction. The analysis of clay minerals took place in two steps, via separation of the less than $2 \mu$ fraction and then $\mathrm{x}$ - ray diffraction technique. The $<2 \mu$ clay fraction was filtered through a ceramic filter using a suction pump. The filtrate was collected in dishes and kept in an oven at 50 0C for subsequent analysis. From the wet clay fraction $(<2 \mu)$ oriented mounds were prepared on glass slides to obtain basal reflections of clay. The thus prepared glass slides were kept in desiccators for 24 hours to dry and then taken for air-drying measurements (Showgi, 2011; Showgi et al., 2016).

The $\mathrm{x}$ - ray diffraction (XRD) analysis was used to identify quantitatively and semi- quantitative the proportion of each clay mineral with respect to other clay minerals present in the tested samples. The concise summary of the application and interpretation of the XRD techniques that was provided by Tucker (1988) was followed and that the qualification of these minerals was made following Thorez (1972). The XRD analyses were performed using Simians D500x-ray diffractometer. The clay minerals were identified from their 0.01 repeated basal reflections that were obtained from the XRD patterns after air drying (normal), glycolation for 48 hours and after heating to $550 \mathrm{C}^{0}$ for four hours. The relative proportion of each mineral was estimated as provided by Thorez, (1975). The total association of minerals was taken to be equal to100 percent. The heights of peaks of the basal reflection 0.01 of the clay mineral were measured above the background and considered as the proportion of that mineral in the sample. The most basic application of XRD to sediments is in the analysis of the Bulk minerals (whole soil samples), to obtain satisfactory results, the original grain size must be reduced to a mean particles diameter of $5-10$ um with performable a limited size range. Care must be taken in particle size reduction. Having ground representative sample to the appropriate grain size, the next stage is to present the sample to the XRD beam.

\section{Results and Discussion}

$\mathrm{X}$ - Ray diffraction analyses of samples in these profiles indicates that the dominant clay mineral is smectite with percentage range between $(71.3-36.1 \%)$ followed by kaolinite (46.45 - 22.2\%), chlorite (6.8 - 1.2 $\%)$, Illite (15.32 - $2.6 \%)$ and SmelChlorite (6.9 $-1.0 \%)$ respectively (Table 4and Figures 4, 6, 8, 10, 12, 14, 16 and 18). The bulk mineral analyses indicated that the presence of high pyroxene is in profile 4 only with percentage of 68.4 ; quartz is 
present in all profiles with percentages of $69.2,12.5,35.1,86.8,31.7,31.6,50.1$ and 50.6; feldspar exists in all Profiles except profile 4,3 and 2 with percentages of 13.8 , 52,0, 24.0,11.1, 20.6; Micais present only in profile 8 with percentage of 16.9 ; Kaolinite exist in Profiles 9, 8, 6 and 3 with percentages of 8.9, 1.9, 2.1and with traces in profile 4, Sodalite and clinochlore are showed only in profiles 7 and 5 with percentages of $(0.9,6.9)$. (28.4, 40.7) respectively; Magnetite exsist in profiles 9, 7 with percentages of $2.5,11.7$; Albite also found in profiles 3 and 2 with percentage 49.3 and 49.4; vermiculite exist in profile 9 with percentage 5.6 (Table 5 and Figures 5; $7 ; 9 ; 11 ; 13 ; 15 ; 17$ and 19$)$.

Table.1 Rainfall at the Study Area

\begin{tabular}{|c|c|c|c|c|c|c|c|}
\hline Season & $\begin{array}{c}\text { Al } \\
\text { Abbasiyia }\end{array}$ & $\begin{array}{c}\text { AL } \\
\text { Terter }\end{array}$ & $\begin{array}{c}\text { Abu } \\
\text { Jubayahah }\end{array}$ & Season & $\begin{array}{c}\text { Al } \\
\text { Abbasiyia }\end{array}$ & $\begin{array}{c}\text { AL } \\
\text { Terter }\end{array}$ & $\begin{array}{c}\text { Abu } \\
\text { Jubayahah }\end{array}$ \\
\hline $\mathbf{1 9 9 7 - 9 8}$ & 482.4 & 667.4 & 573.5 & $\mathbf{2 0 0 2}-\mathbf{0 3}$ & 510 & 509 & 526 \\
\hline $\mathbf{1 9 9 8}-\mathbf{9 9}$ & 668 & - & 472 & $\mathbf{2 0 0 3}-\mathbf{0 4}$ & 554.5 & 499.6 & 812 \\
\hline $\mathbf{1 9 9 9}-\mathbf{0 0}$ & 555.6 & 506 & 568 & $\mathbf{2 0 0 4}-\mathbf{0 5}$ & 532.5 & 414 & 661.5 \\
\hline $\mathbf{2 0 0 0}-\mathbf{- 0 1}$ & 477 & 483 & 614 & $\mathbf{2 0 0 5}-\mathbf{0 6}$ & 555.7 & 427 & 662 \\
\hline $\mathbf{2 0 0 1}-\mathbf{0 2}$ & 589 & 711 & 638 & $\mathbf{2 0 0 6}-\mathbf{0 7}$ & 723.3 & 749.4 & 671.5 \\
\hline
\end{tabular}

Table.2 Sample sites, location and elevation along the toposequence

\begin{tabular}{|c|c|c|c|c|}
\hline Area & Sample site & North & East & Elevation (m) \\
\hline \multirow{8}{*}{$\begin{array}{c}\text { Al Abbasyia, Terter } \\
\text { and } \\
\text { Megenis } \\
\text { (Middle and } \\
\text { lower slope) }\end{array}$} & AT009 & $12^{\circ} 08^{\prime} 32.00^{\prime \prime}$ & $31^{\circ} 18^{\prime} 05.00^{\prime \prime}$ & 561 \\
\hline & AT008 & $12^{\circ} 09^{\prime} 21.00^{\prime \prime}$ & $31^{\circ} 27^{\prime} 41.00^{\prime \prime}$ & 541 \\
\hline & AT007 & $12^{\circ} 05^{\prime} 09.00^{\prime \prime}$ & $31^{\circ} 39^{\prime} 35.00^{\prime \prime}$ & 523 \\
\hline & AT006 & $12^{\circ} 03^{\prime} 51.00^{\prime \prime}$ & $31^{\circ} 44^{\prime} 42.00^{\prime \prime}$ & 503 \\
\hline & AT005 & $11^{\circ} 55^{\prime} 52.00^{\prime \prime}$ & $31^{\circ} 45^{\prime} 20.00^{\prime \prime}$ & 473 \\
\hline & AT004 & $11^{\circ} 55^{\prime} 57.00^{\prime \prime}$ & $31^{\circ} 52^{\prime} 28.00^{\prime \prime}$ & 451 \\
\hline & ME003 & $11^{\circ} 56^{\prime} 02.00^{\prime \prime}$ & $32^{\circ} 15^{\prime} 43.00^{\prime \prime}$ & 437 \\
\hline & ME002 & $11^{\circ} 56^{\prime} 22.00^{\prime \prime}$ & $32^{\circ} 33^{\prime} 55.00^{\prime \prime}$ & 406 \\
\hline $\begin{array}{c}\text { White Nile } \\
\text { Terrace }\end{array}$ & ME001 & $11^{\circ} 56^{\prime} 52.00^{\prime \prime}$ & $32^{\circ} 40^{\prime} 43.00^{\prime \prime}$ & 381 \\
\hline
\end{tabular}

Table.3 Clay Minerals Analyses of Soil Samples from Study area

\begin{tabular}{|c|l|l|l|l|l|l|}
\hline Area & $\begin{array}{l}\text { Profile } \\
\text { No }\end{array}$ & $\begin{array}{l}\text { Smectite } \\
\mathbf{\%}\end{array}$ & $\begin{array}{l}\text { Kaolinite } \\
\mathbf{\%}\end{array}$ & $\begin{array}{l}\text { Illite } \\
\mathbf{\%}\end{array}$ & $\begin{array}{l}\text { Chlorite } \\
\mathbf{\%}\end{array}$ & $\begin{array}{l}\text { Sme/Chl. } \\
\mathbf{\%}\end{array}$ \\
\hline \multirow{2}{*}{$\begin{array}{c}\text { Al- } \\
\text { Abbasyia }\end{array}$} & AT 009 & 71.0 & 24.8 & 2.6 & 1.2 & 1.4 \\
\cline { 2 - 7 } & AT 008 & 46.3 & 34.8 & 8.4 & 3.6 & 6.9 \\
\cline { 2 - 7 } & AT 007 & 65.6 & 29.0 & 2.8 & 1.5 & 1.1 \\
\cline { 2 - 7 } & AT 006 & 71.3 & 22.2 & 3.9 & 1.2 & 1.4 \\
\hline \multirow{2}{*}{ Al-Terter } & AT 005 & 36.1 & 46.4 & 11.6 & 4.4 & 1.5 \\
\cline { 2 - 7 } & AT 004 & 64.1 & 25.4 & 4.6 & 3.2 & 2.7 \\
\hline \multirow{2}{*}{ Megenis } & MG003 & 41.00 & 46.45 & 10.63 & 1.95 & 1.0 \\
\cline { 2 - 7 } & MG002 & 37.01 & 39.57 & 15.32 & 6.8 & 1.5 \\
\hline \multirow{2}{*}{$\begin{array}{c}\text { White } \\
\text { Nile }\end{array}$} & ME001 & 85.11 & 11.5 & 1.25 & 0.8 & 1.34 \\
\hline
\end{tabular}


Table.4 Bulk Minerals Analyses of the Study Area Soil Samples

\begin{tabular}{|c|c|c|c|c|c|c|c|c|c|c|c|c|}
\hline \multirow{4}{*}{ The area } & \multirow{4}{*}{$\begin{array}{c}\text { Sample } \\
\text { No }\end{array}$} & \multicolumn{11}{|c|}{ Detrital Mineral grain } \\
\hline & & \multicolumn{9}{|c|}{ Silicates } & \multirow{2}{*}{\multicolumn{2}{|c|}{$\begin{array}{c}\text { Non - } \\
\text { silicates }\end{array}$}} \\
\hline & & \multicolumn{3}{|c|}{ Sand + Silt } & \multicolumn{6}{|c|}{ Clay } & & \\
\hline & & $\begin{array}{c}\text { Pyroxene } \\
\% \\
\end{array}$ & $\begin{array}{c}\text { Feldspars } \\
\% \\
\end{array}$ & $\begin{array}{c}\text { Quartz } \\
\%\end{array}$ & $\begin{array}{c}\text { Mica } \\
\% \\
\end{array}$ & Albite\% & Kainite\% & $\begin{array}{c}\text { Kaolinite } \\
\%\end{array}$ & Vermiculite\% & $\begin{array}{c}\text { Sodalite } \\
\%\end{array}$ & $\begin{array}{c}\text { Clinochlore } \\
\%\end{array}$ & Magnetite \% \\
\hline \multirow{4}{*}{ Al-Abbasyia } & TE009 & - & 13.8 & 69.2 & - & & Traces & 8.9 & 5.6 & - & - & 2.5 \\
\hline & TE008 & - & 52.0 & 12.5 & 16.9 & & - & 1.9 & - & traces & - & traces \\
\hline & TE007 & - & 24.0 & 35.1 & - & & - & - & - & 0.9 & 28.4 & 11.7 \\
\hline & TE006 & - & 11.1 & 86.8 & - & & - & 2.1 & - & - & - & - \\
\hline \multirow[t]{2}{*}{ Al-Terter } & TE005 & - & 20.6 & 31.7 & $\begin{array}{c}\text { Trace } \\
\mathrm{s} \\
\end{array}$ & & - & - & - & 6.9 & 40.7 & - \\
\hline & TE004 & 68.4 & - & 31.6 & - & & Traces & traces & - & - & - & - \\
\hline \multirow{2}{*}{ Megenis } & MG003 & - & - & 50.1 & - & 49.3 & & 0.6 & - & - & - & - \\
\hline & MG002 & - & - & 50.6 & - & 49.4 & - & - & - & - & - & - \\
\hline $\begin{array}{c}\text { White } \\
\text { NileTerrace }\end{array}$ & MG001 & & & 77.1 & & & & 0.4 & & & & 22.5 \\
\hline
\end{tabular}


Fig.1 The Study Area at the Eastern and South Eastern Middle and Lower Clay Plains of Nuba Mountains- South Kordofan State

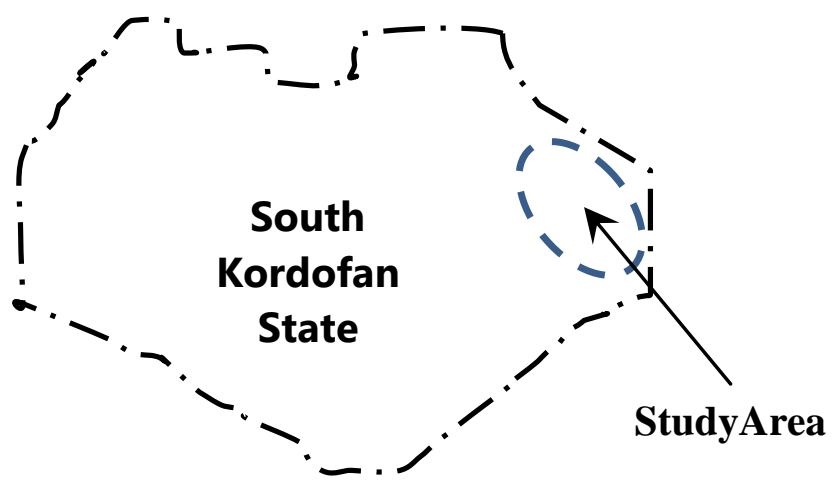

Fig.2 Landsat scene showing the sampling sites starting from Abbasyia(AT009) on the North East to Megenis (ME002) on the South East.
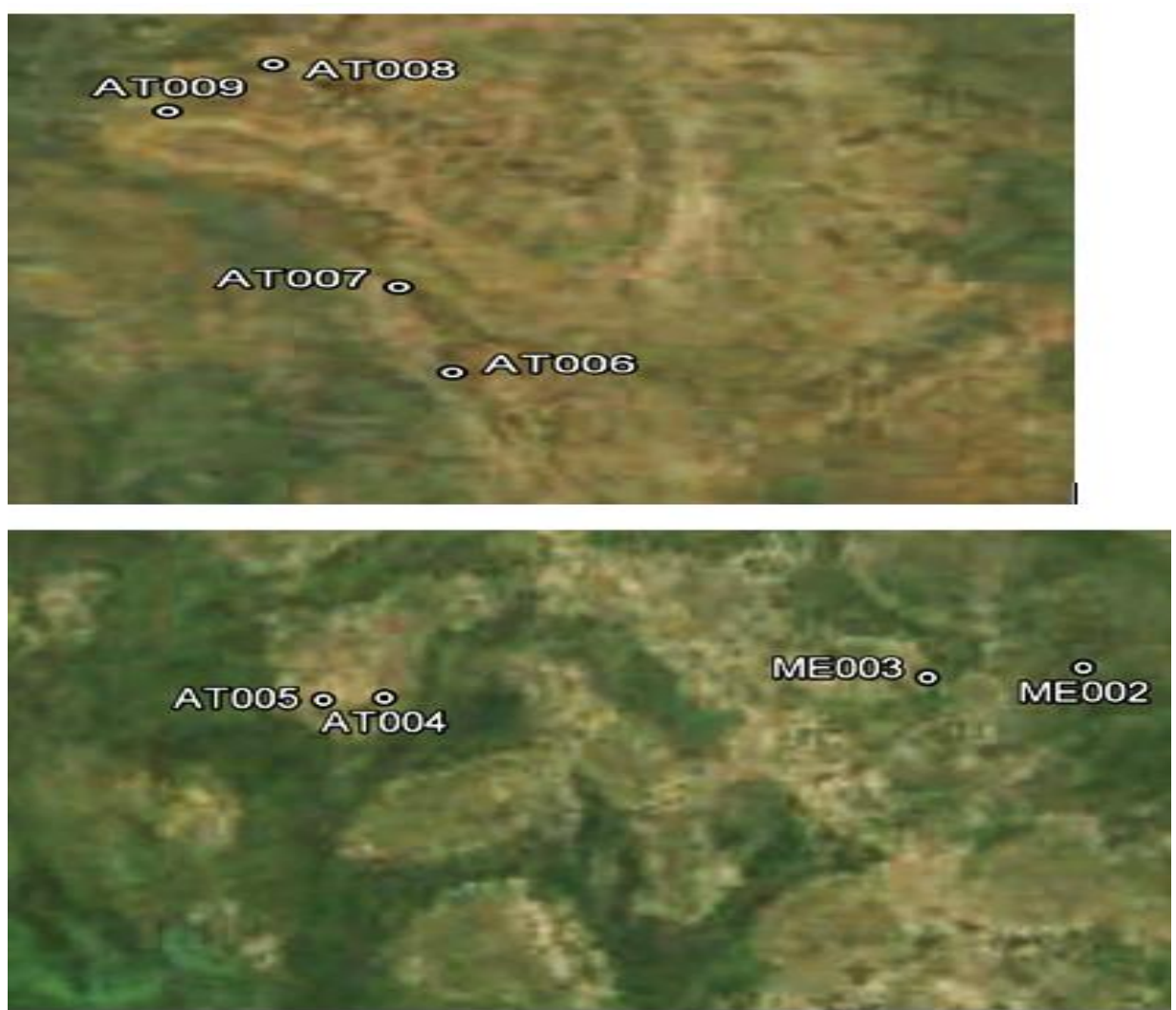

\begin{tabular}{|l|l|l|l|l|l|l|l|}
\hline AT009 & AT008 & AT007 & AT006 & AT005 & AT004 & ME003 & ME002 \\
\hline Abbasyia4 & Abbasyia3 & Abbasyia2 & Abbasyia1 & Al Terter2 & Al-Terter1 & Megenis3 & Megenis2 \\
\hline
\end{tabular}


Fig.3 Topographical Sequence of the Study Sites

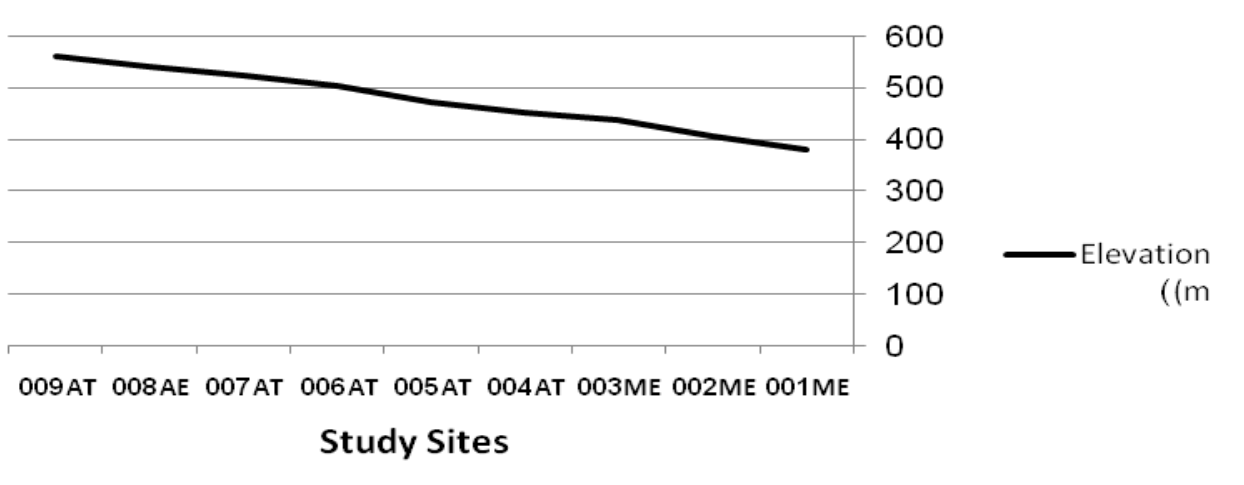

Fig.4 TheXRD pattern of clay minerals of the soil sample from Abbasyia 4 $(42-75 \mathrm{~cm})$

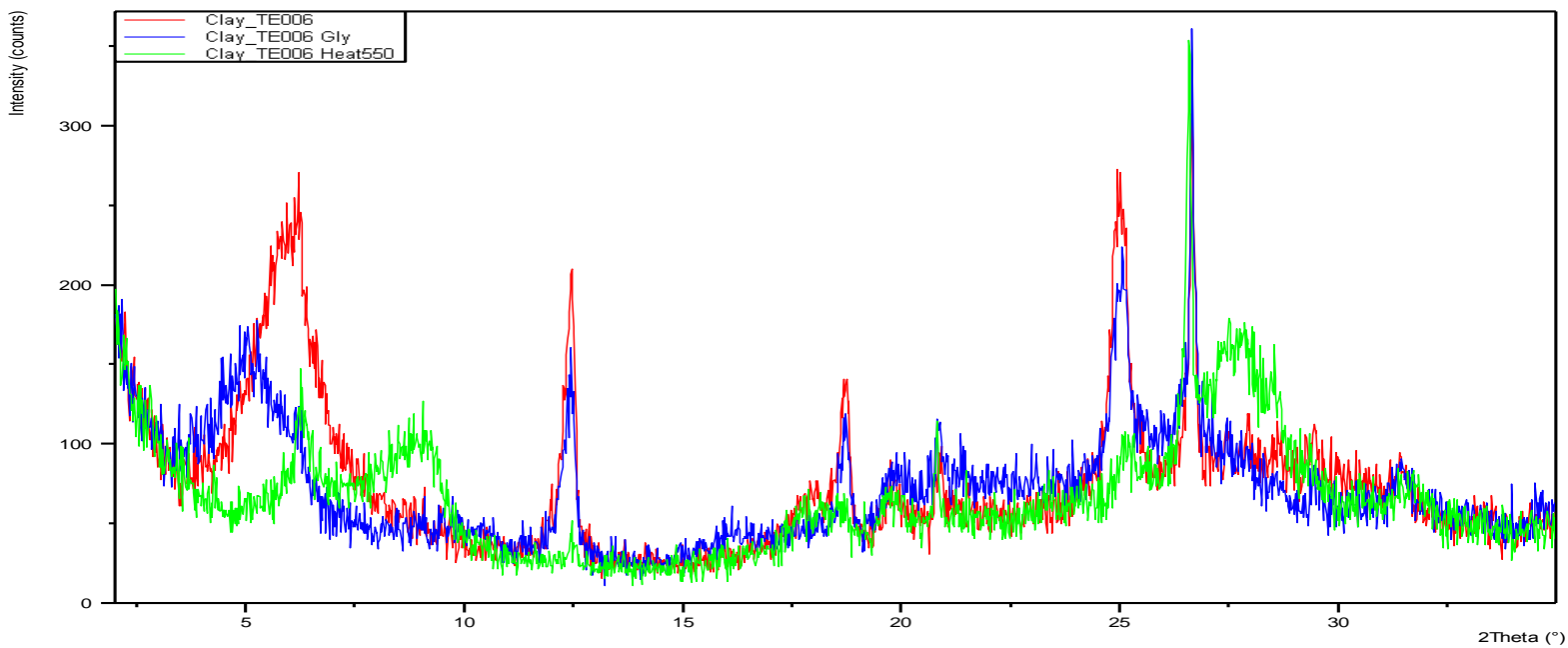

Fig.5 The XRD pattern of bulk minerals of the soil sample from Abbasyia $4(42-75 \mathrm{~cm})$

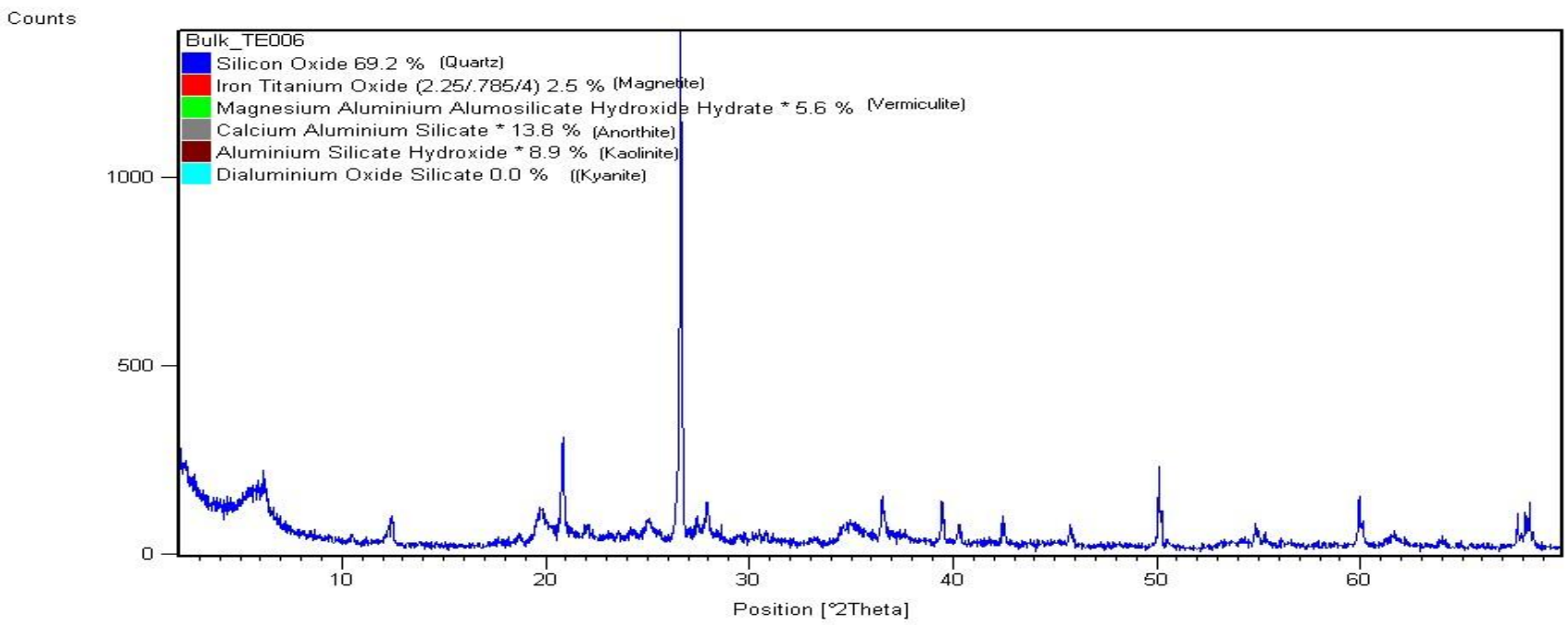


Fig.6 The X RD pattern of clay minerals of the soil sample from Abbasyia $3(43-88 \mathrm{Cm})$

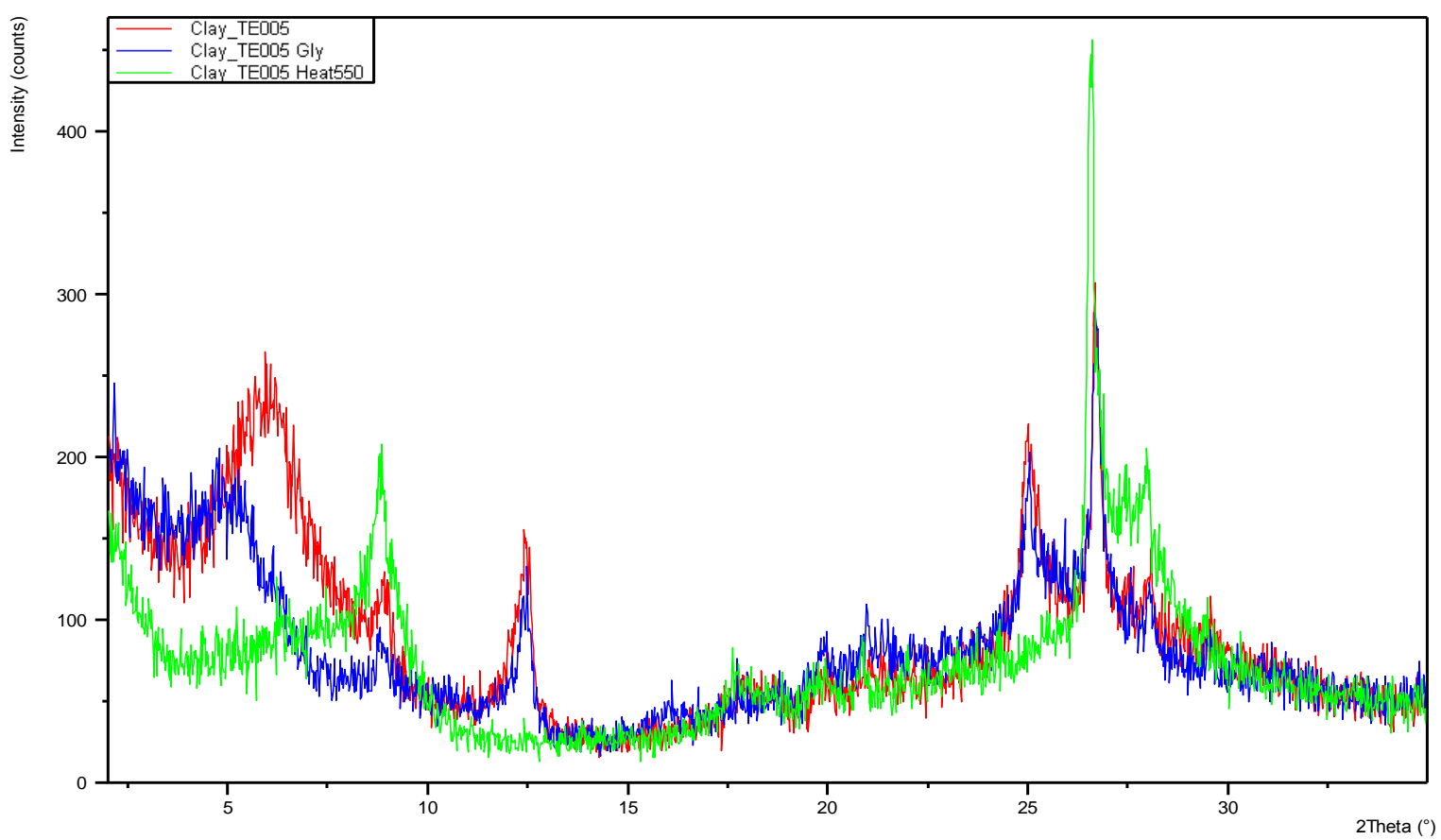

Fig.7 The X RD pattern of Bulk minerals of the soil sample from Abbasyia $3(43-88 \mathrm{Cm})$

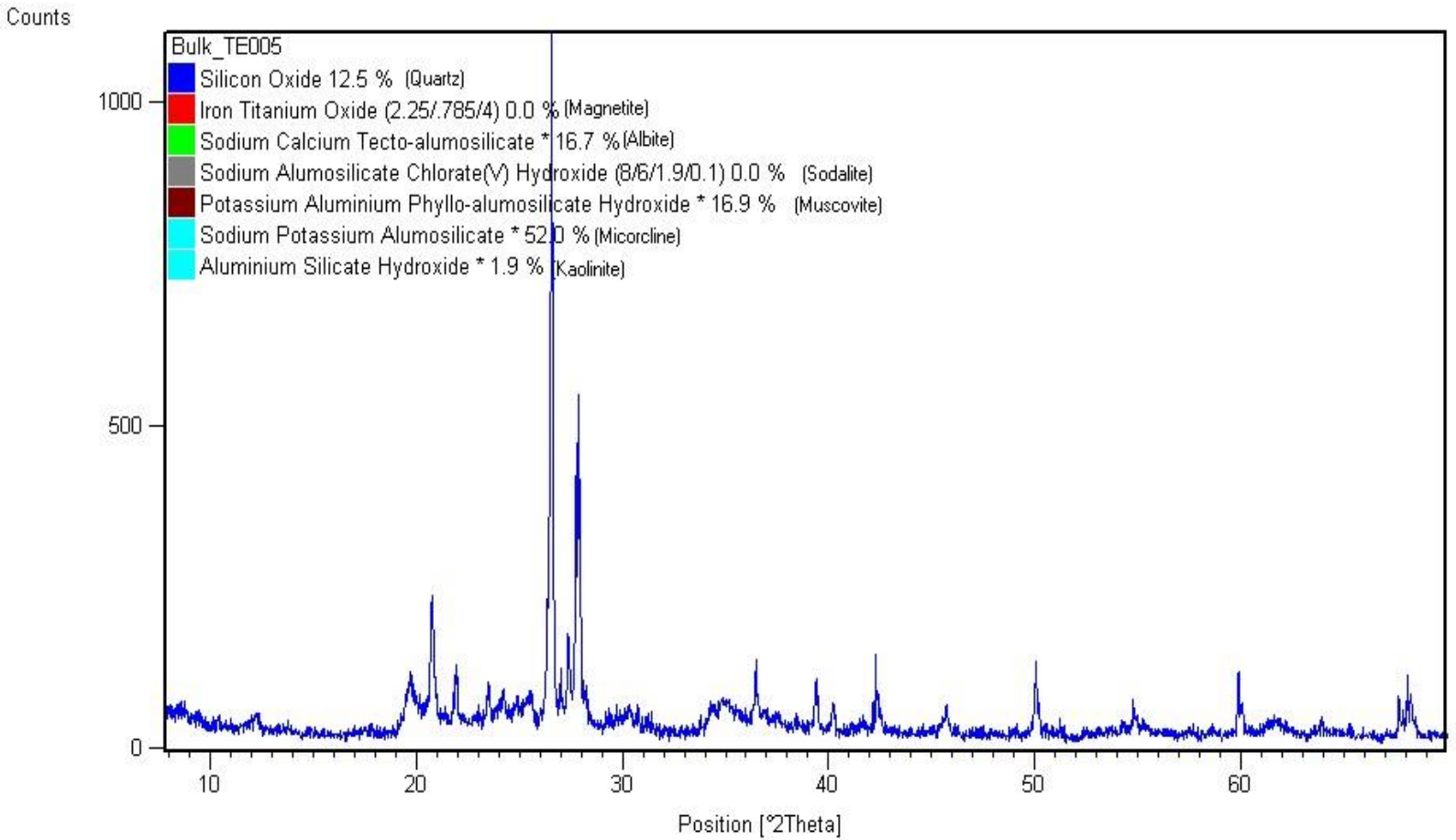


Fig.8 The XRD pattern of clay minerals of the soil sample from Abassiyia $2(58-89 \mathrm{Cm})$

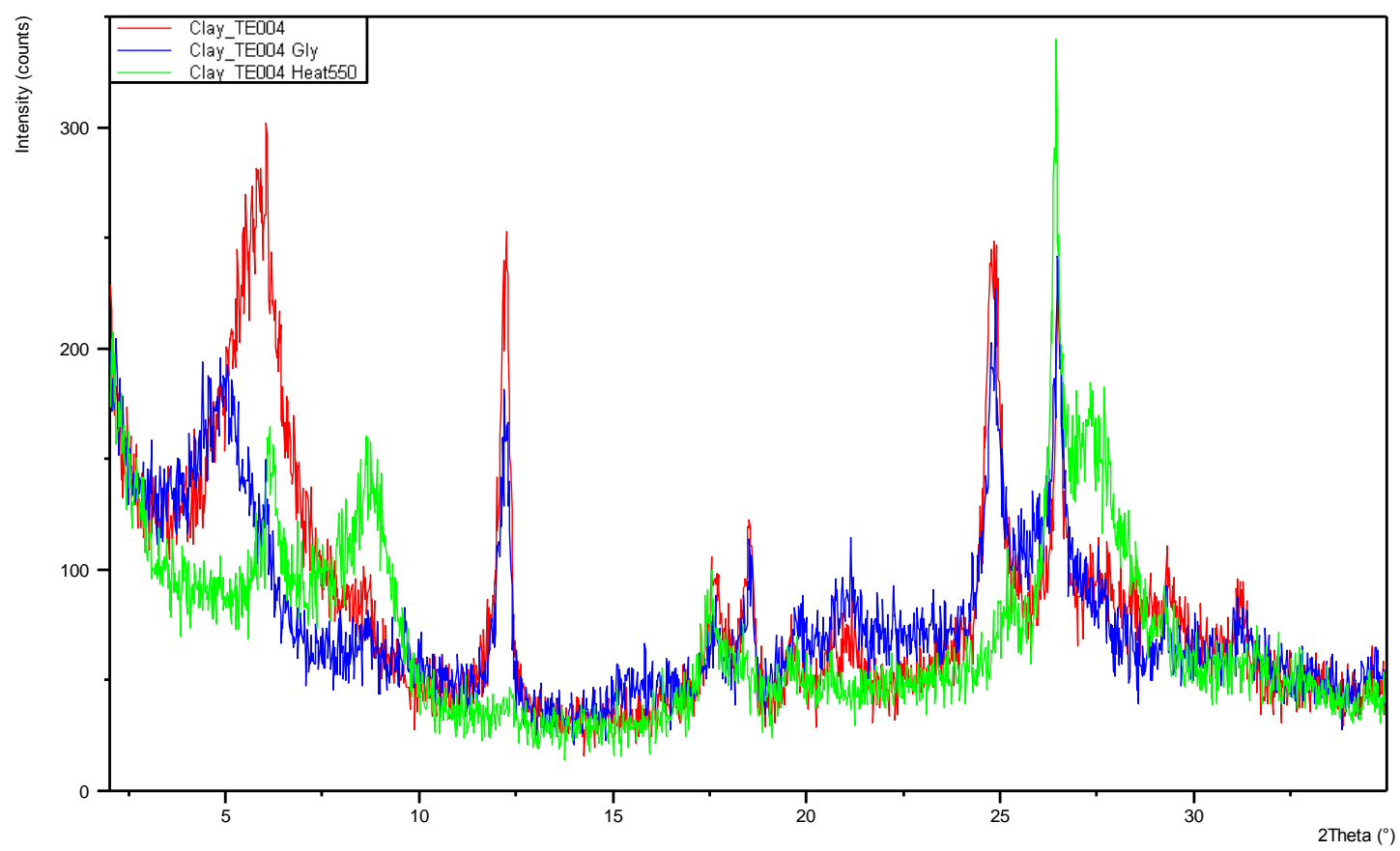

Fig.9 The X RD pattern of bulk minerals of the soil sample from Abbasyia $2(58-89 \mathrm{Cm})$

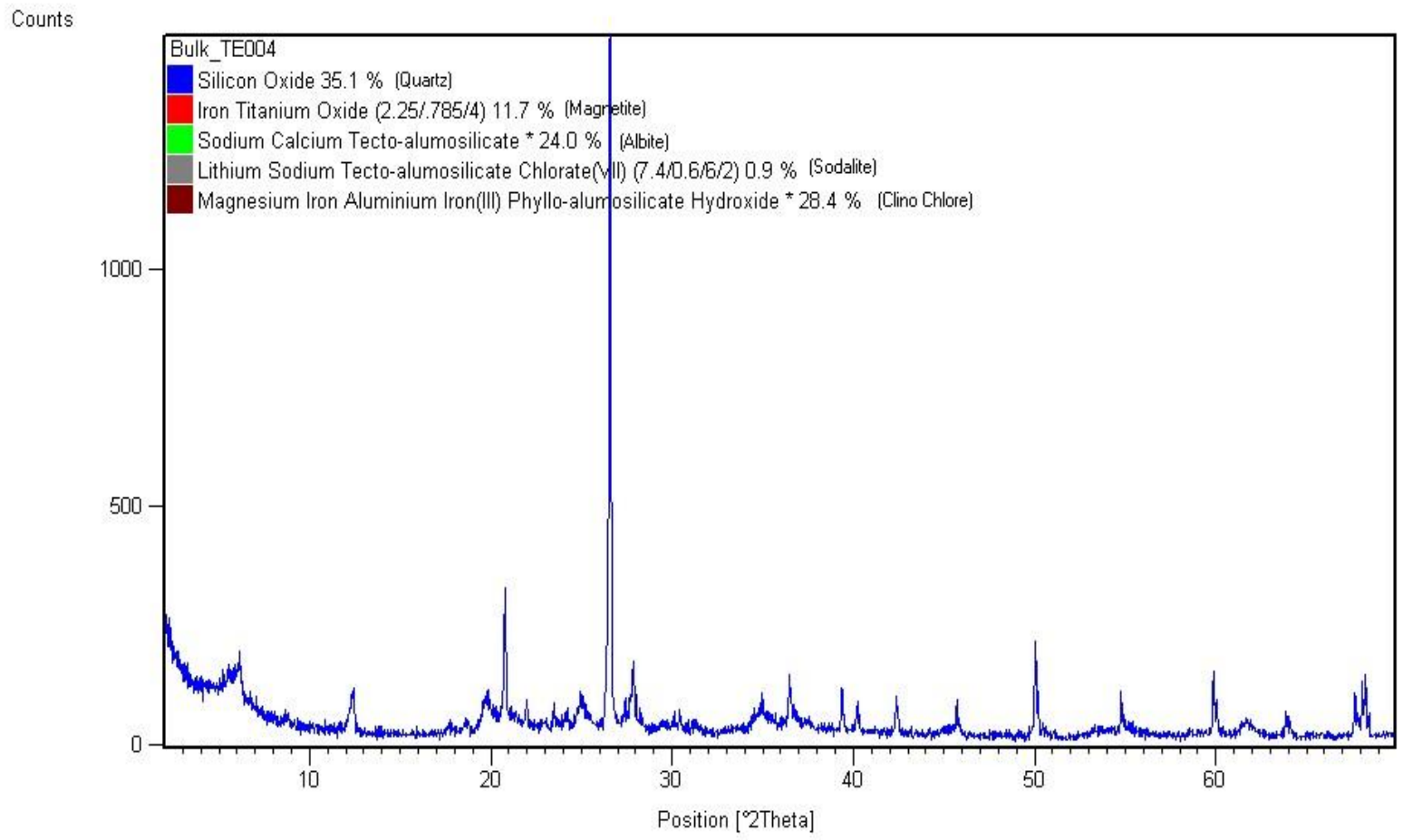


Fig.10 The XRD pattern of clay minerals of the soil sample from Abassiyia $1(57$ - $91 \mathrm{Cm})$

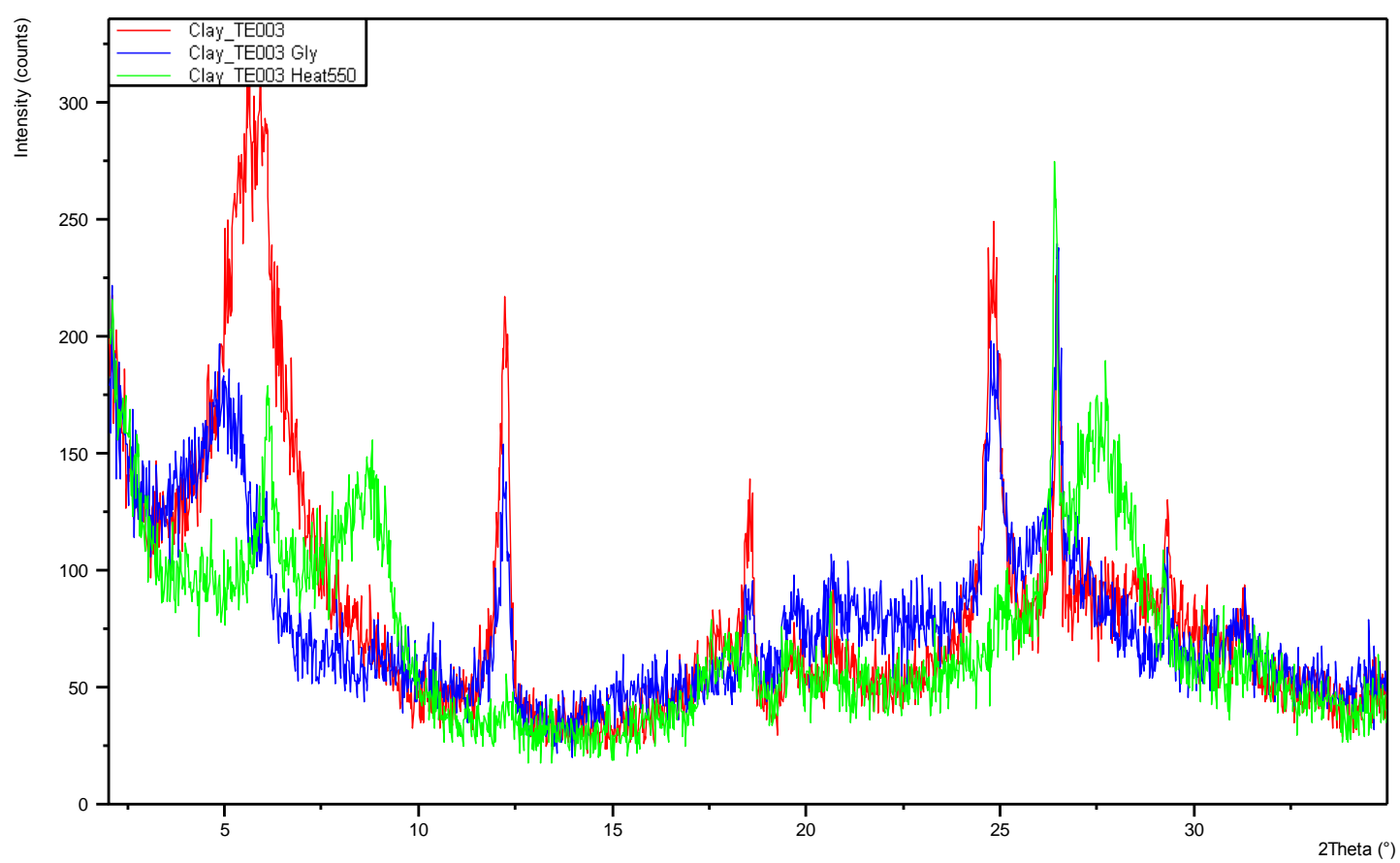

Fig.11 The XRD pattern of bulk minerals of the soil sample from Abassiyia $1(57-91 \mathrm{Cm})$

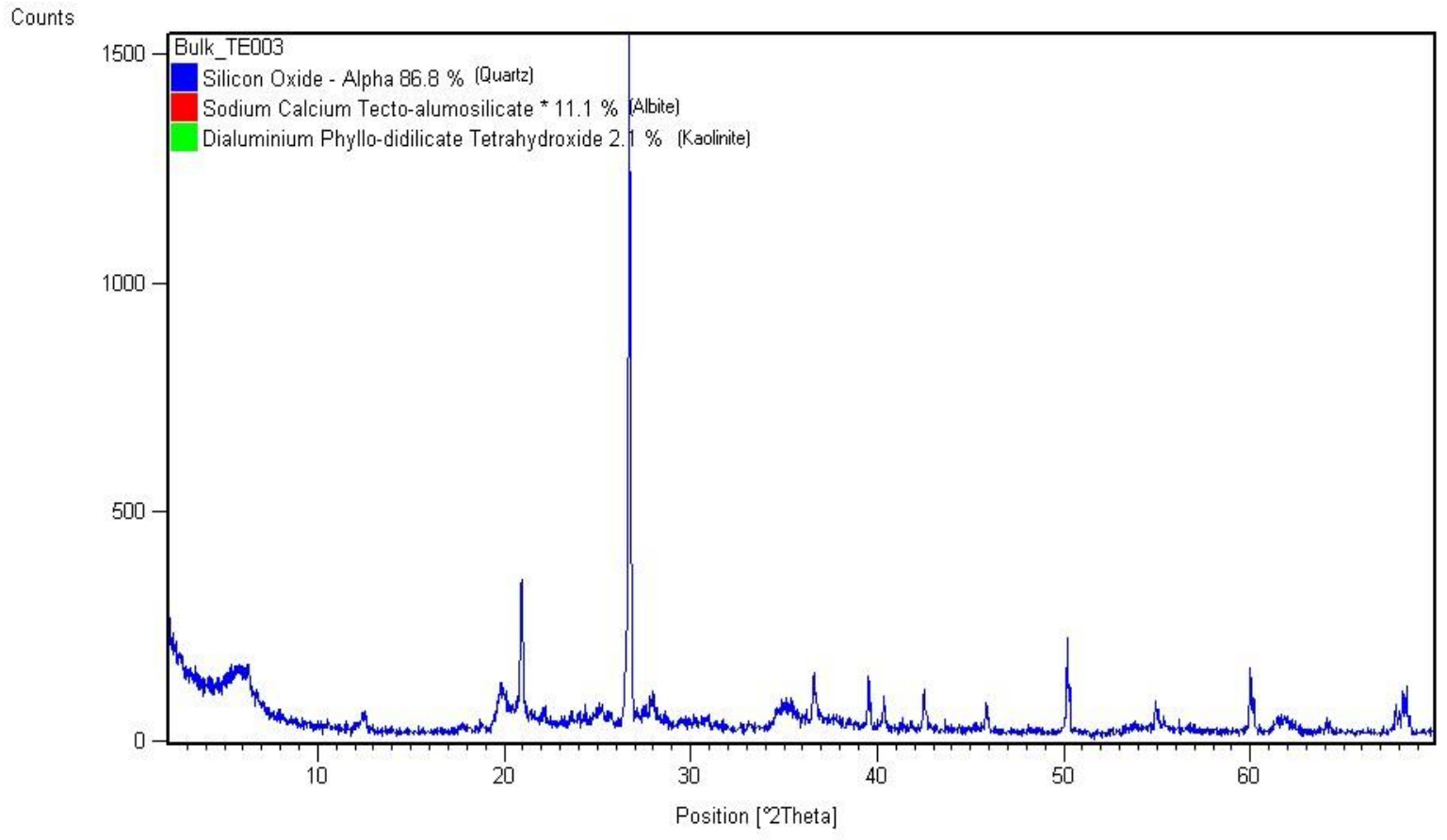


Fig.12 The X - RD pattern of clay minerals of the soil sample from Al terter $2(52-85 \mathrm{Cm})$

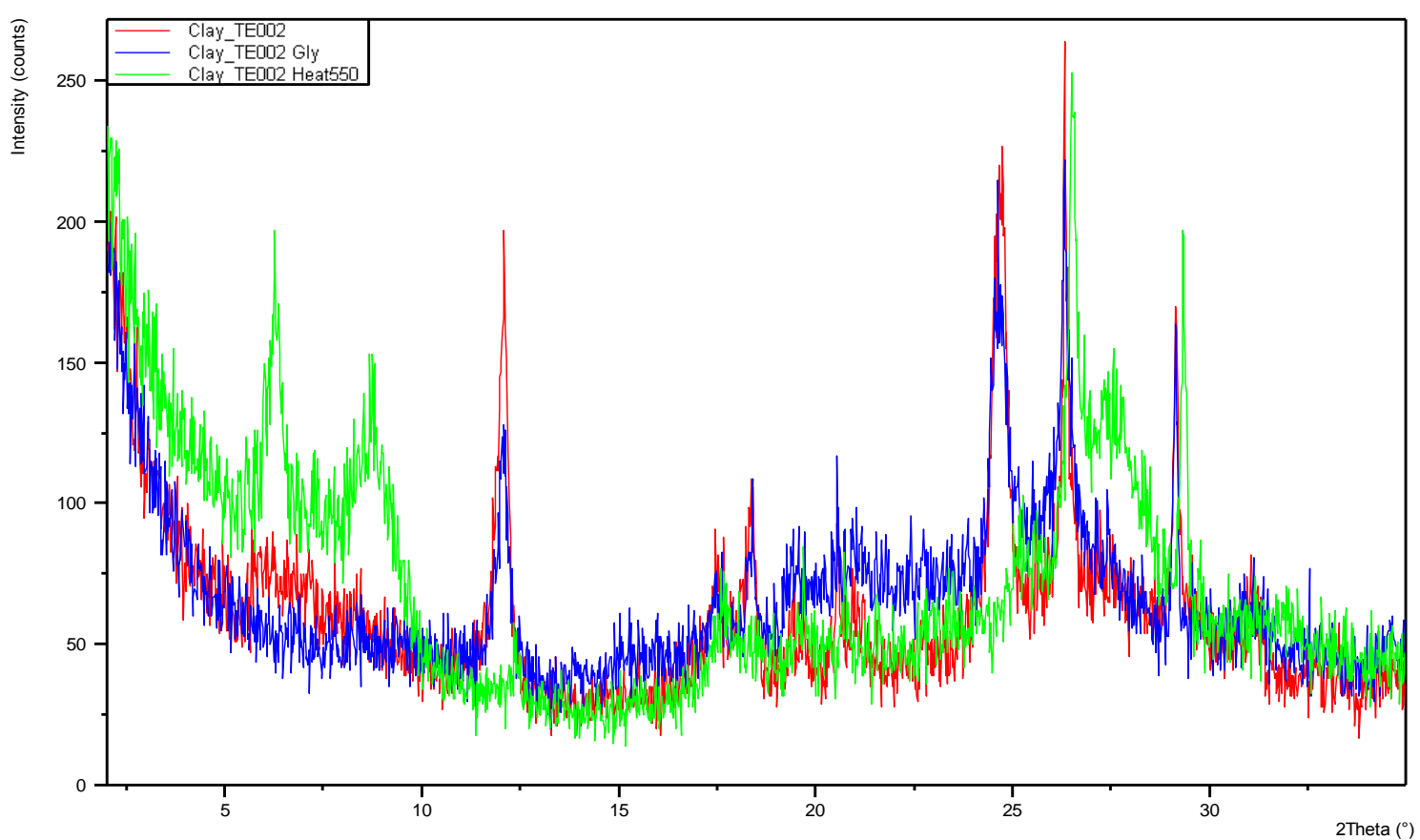

Fig.13 The X RD pattern of bulk minerals of the soil sample from Al Terter $2(52$ - $85 \mathrm{Cm})$

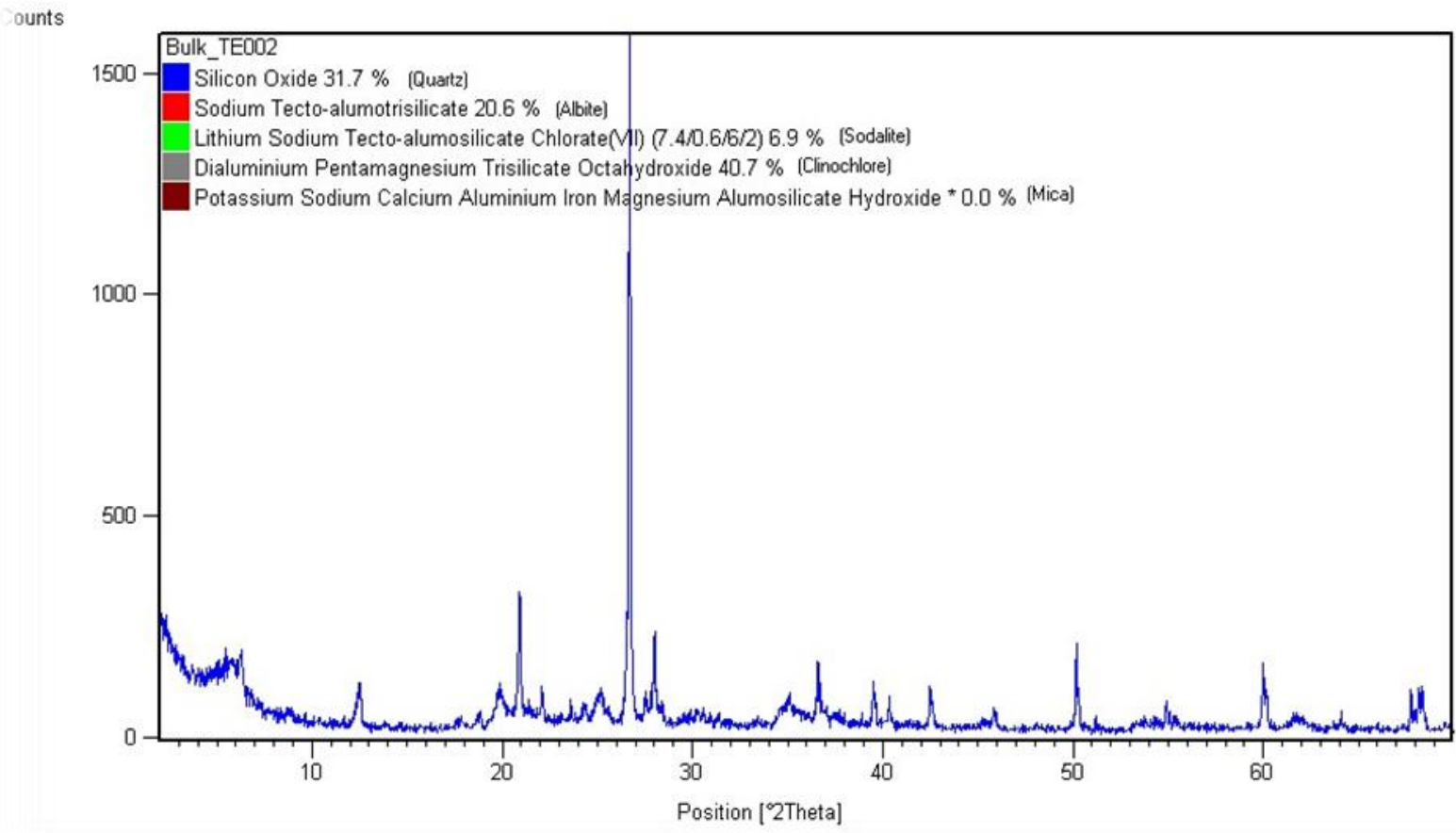


Fig.14 The XRD pattern of clay minerals of the soil sample from Al Terter $1(68-94 \mathrm{~cm})$

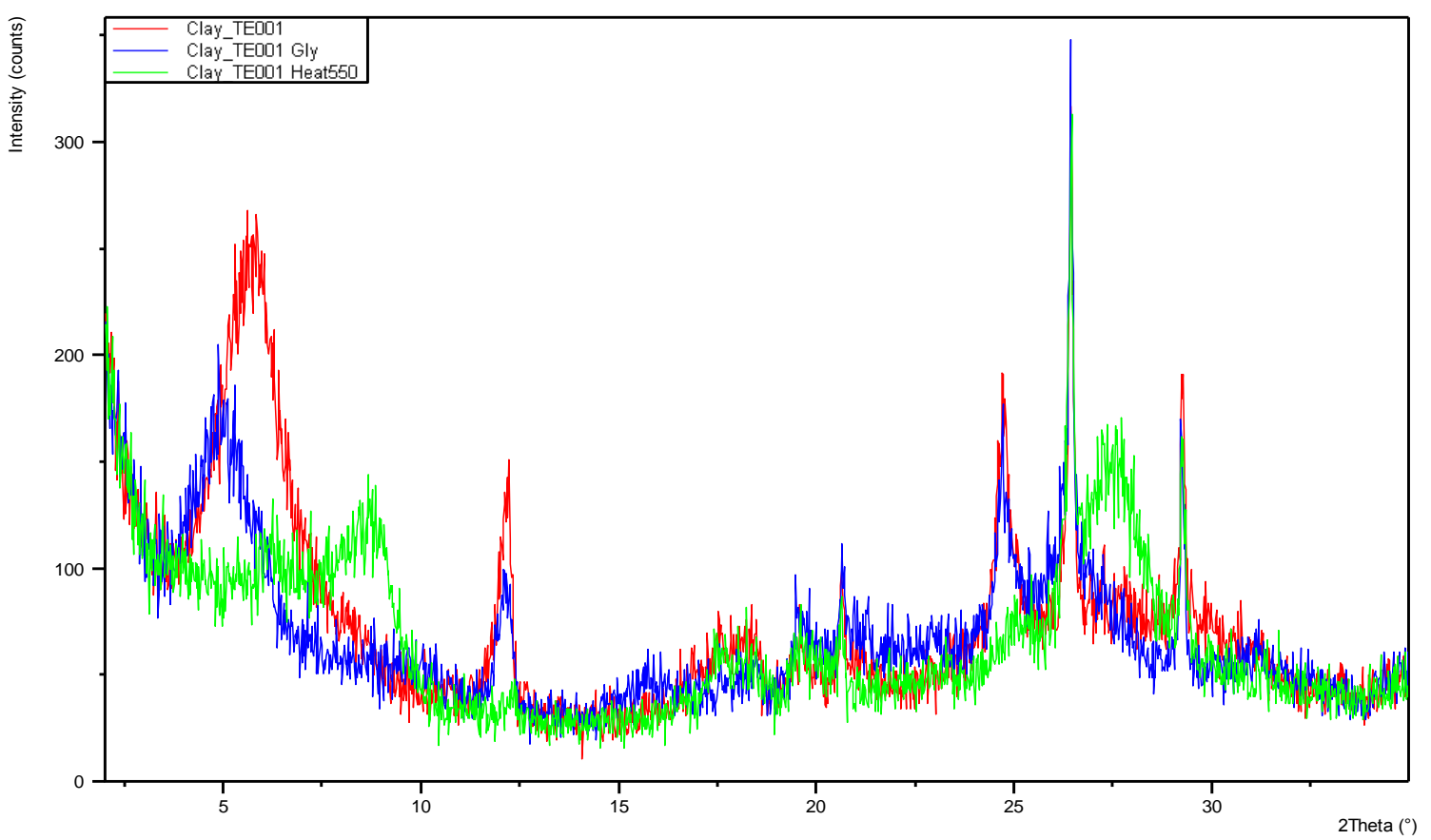

Fig.15 The XRD pattern of bulk minerals of the soil sample from Al Terter 1 (68 -94 cm)

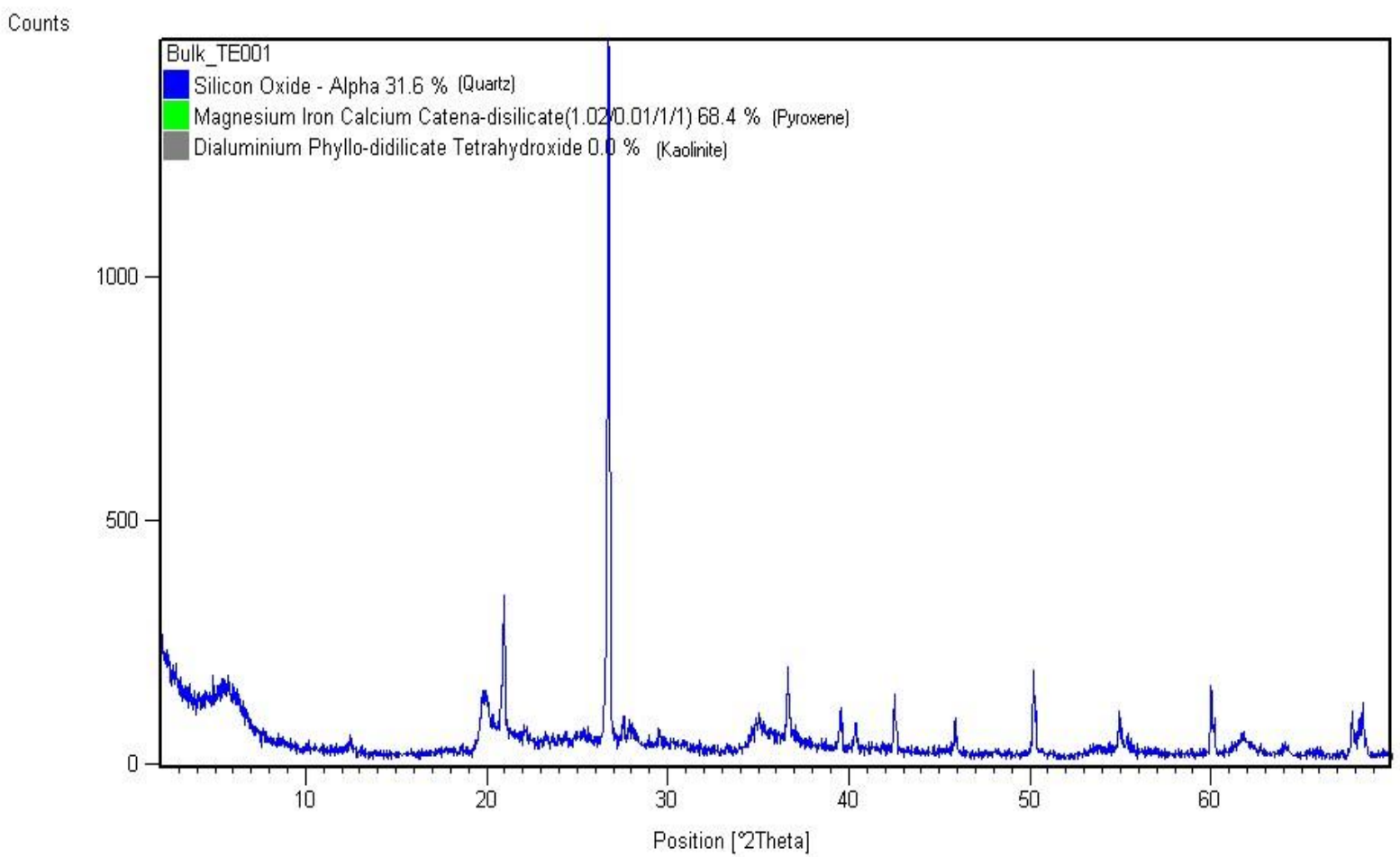


Fig.16 The X RD pattern of clay minerals of the soil sample from Megins $3(96-125 \mathrm{~cm})$

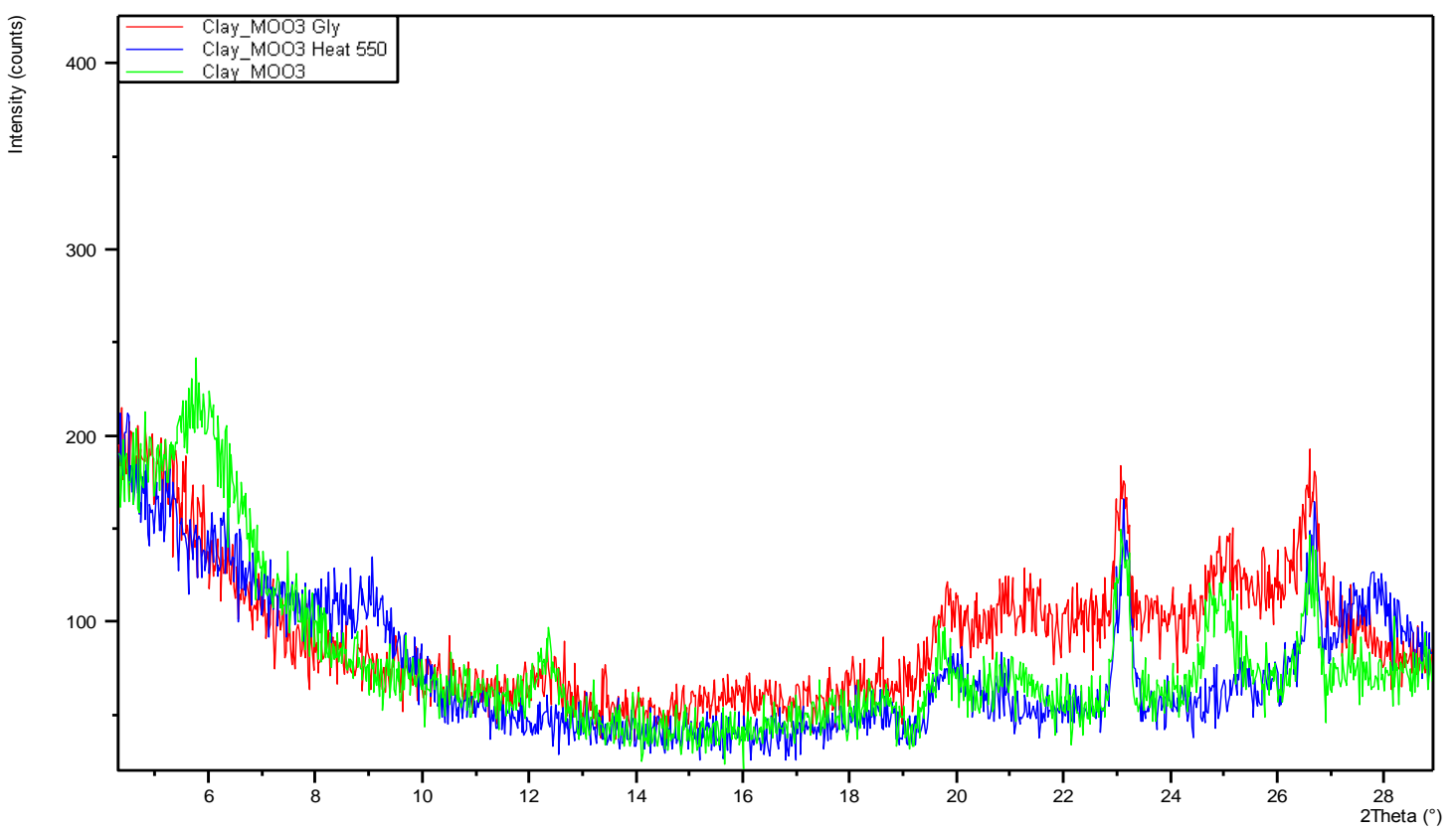

Fig.17 The X RD pattern of bulk minerals of the soil sample from Al Megins $3(86-125 \mathrm{~cm})$

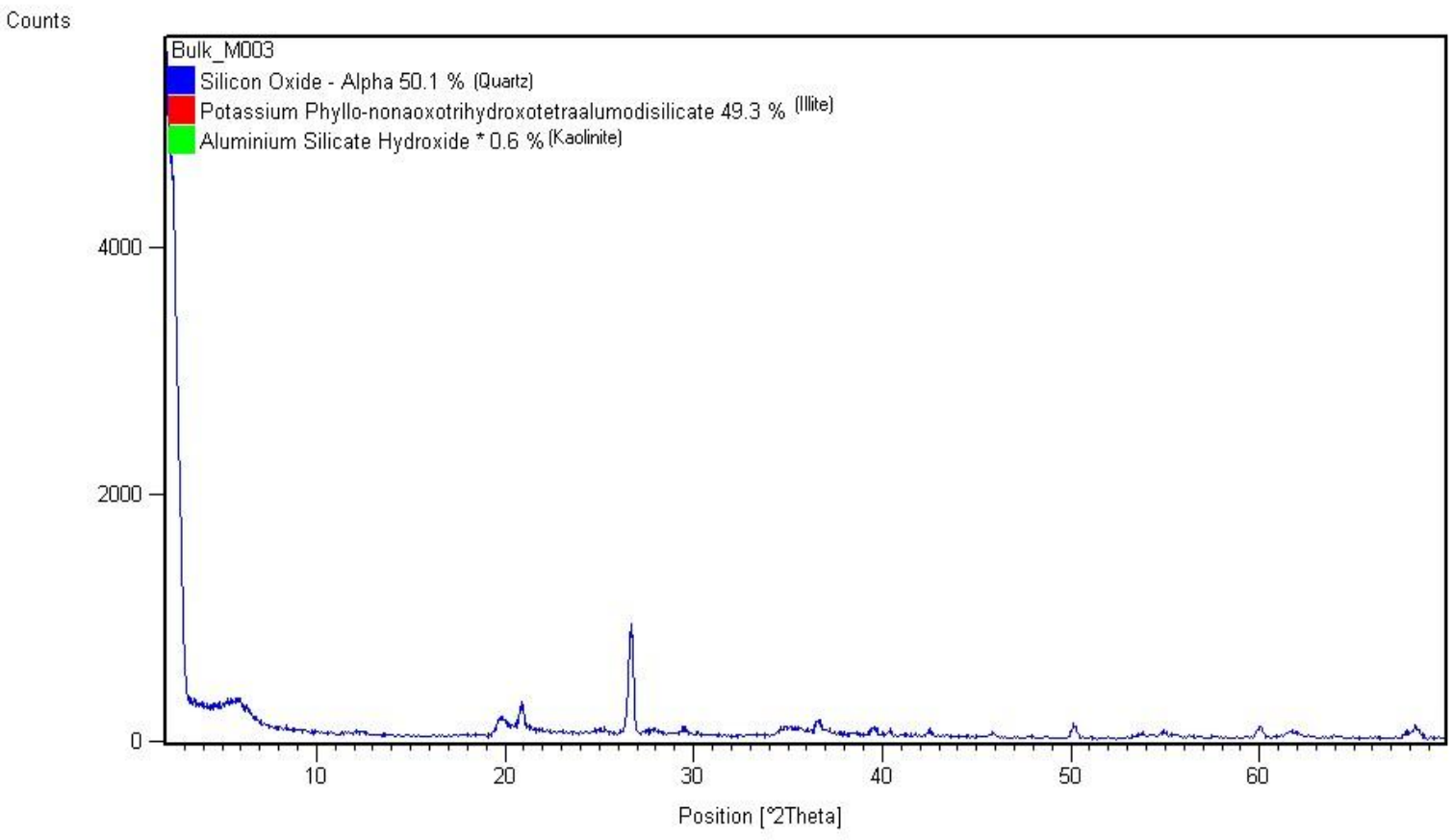


Fig.18 The XRD pattern of clay minerals of the soil sample from Megins $2(87-125 \mathrm{~cm})$

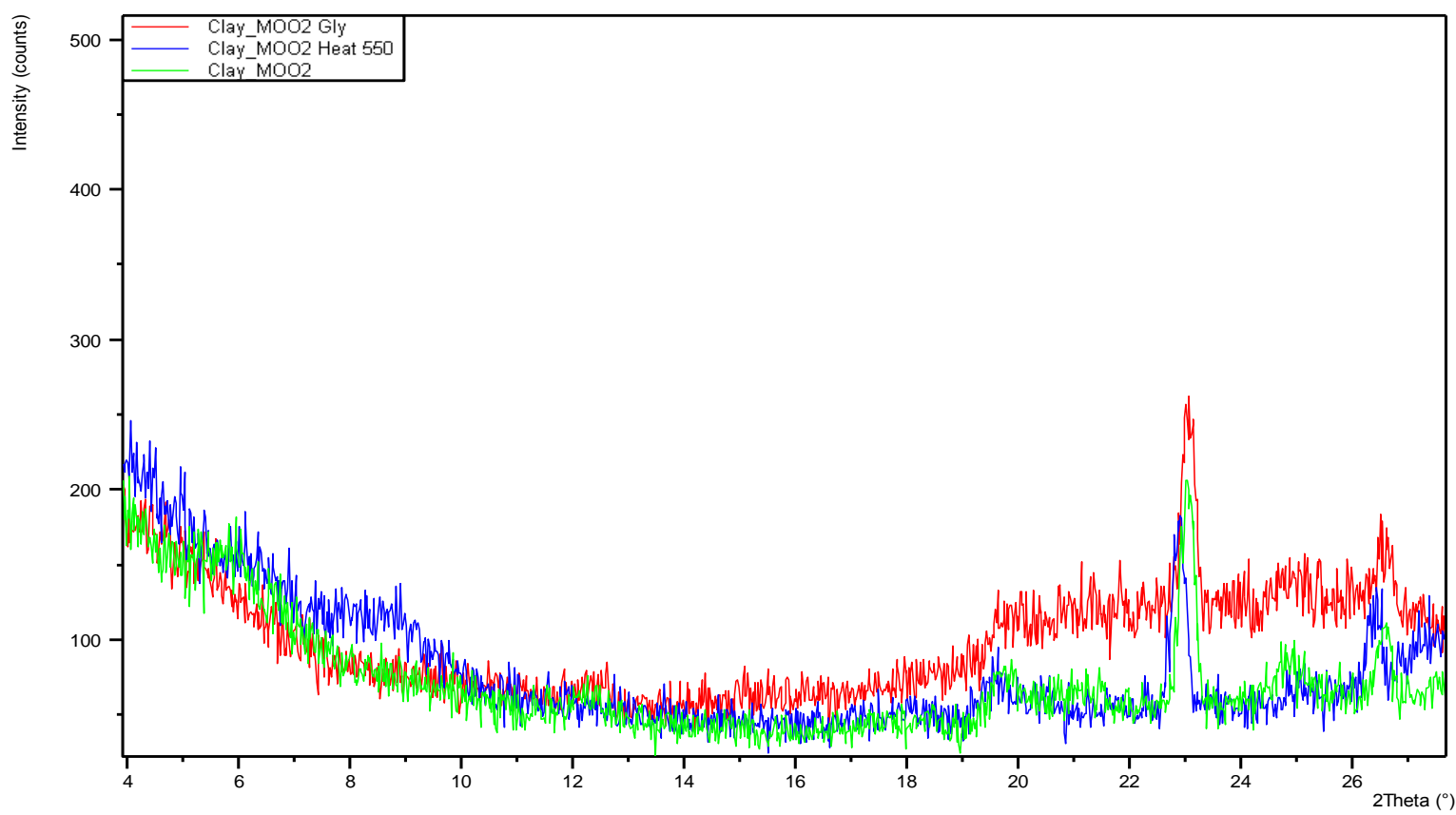

Fig.19 The X RD pattern of bulk minerals of the soil sample from Megins $2(87-125 \mathrm{~cm})$

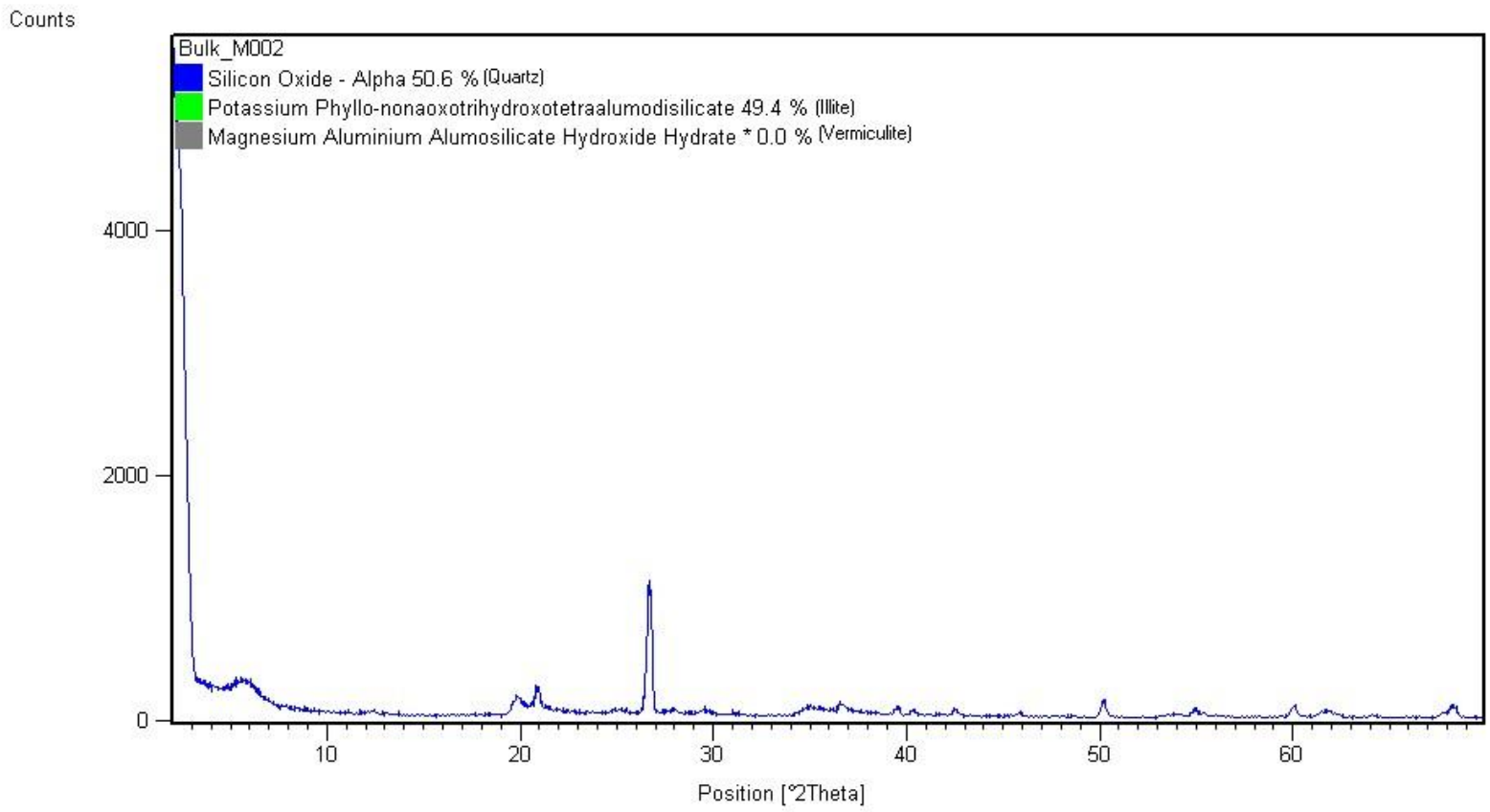


Fig.20 The XRD pattern of clay minerals of the soil sample from White Nile area $(68-94 \mathrm{~cm})$

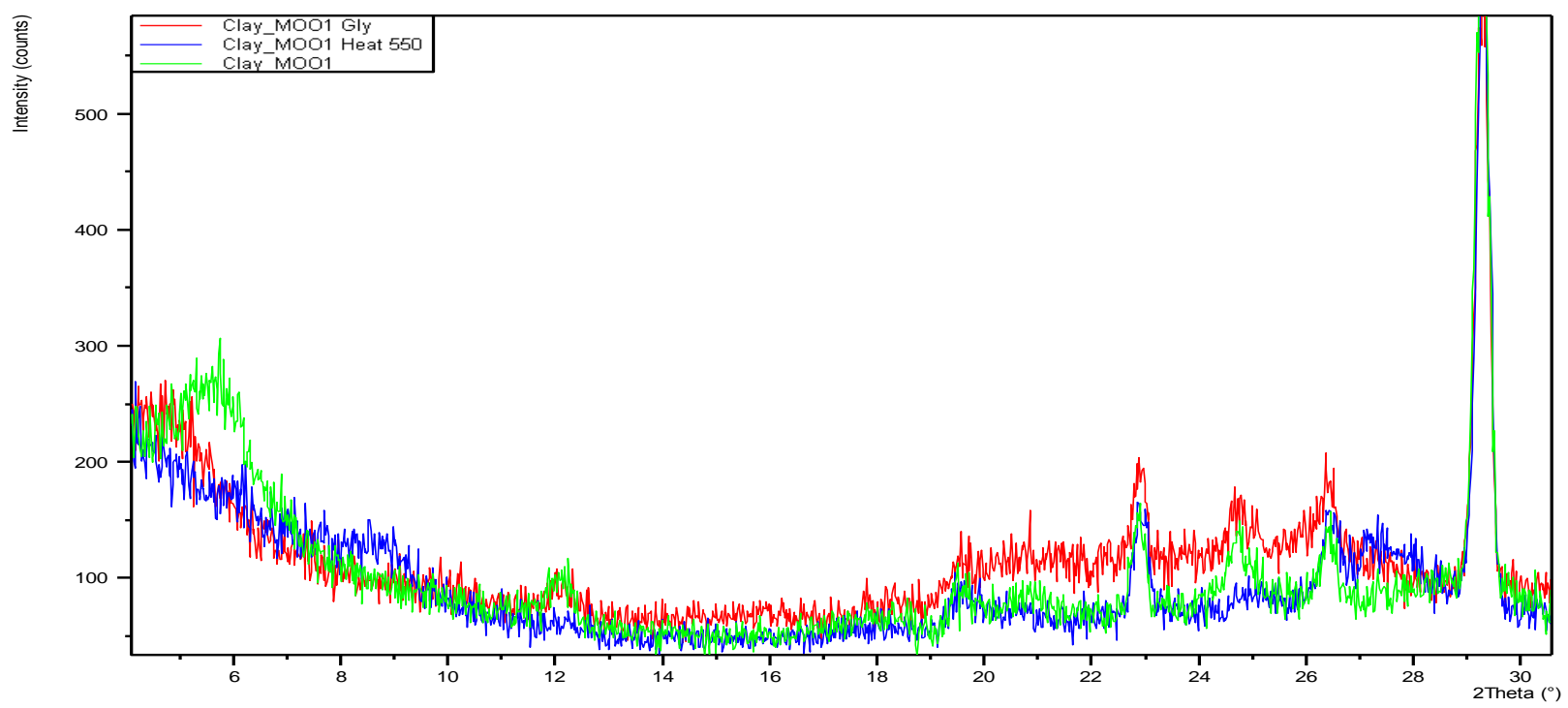

Fig.21 The XRD pattern of bulk minerals of the soil sample from White Nile area $(68-94 \mathrm{~cm})$

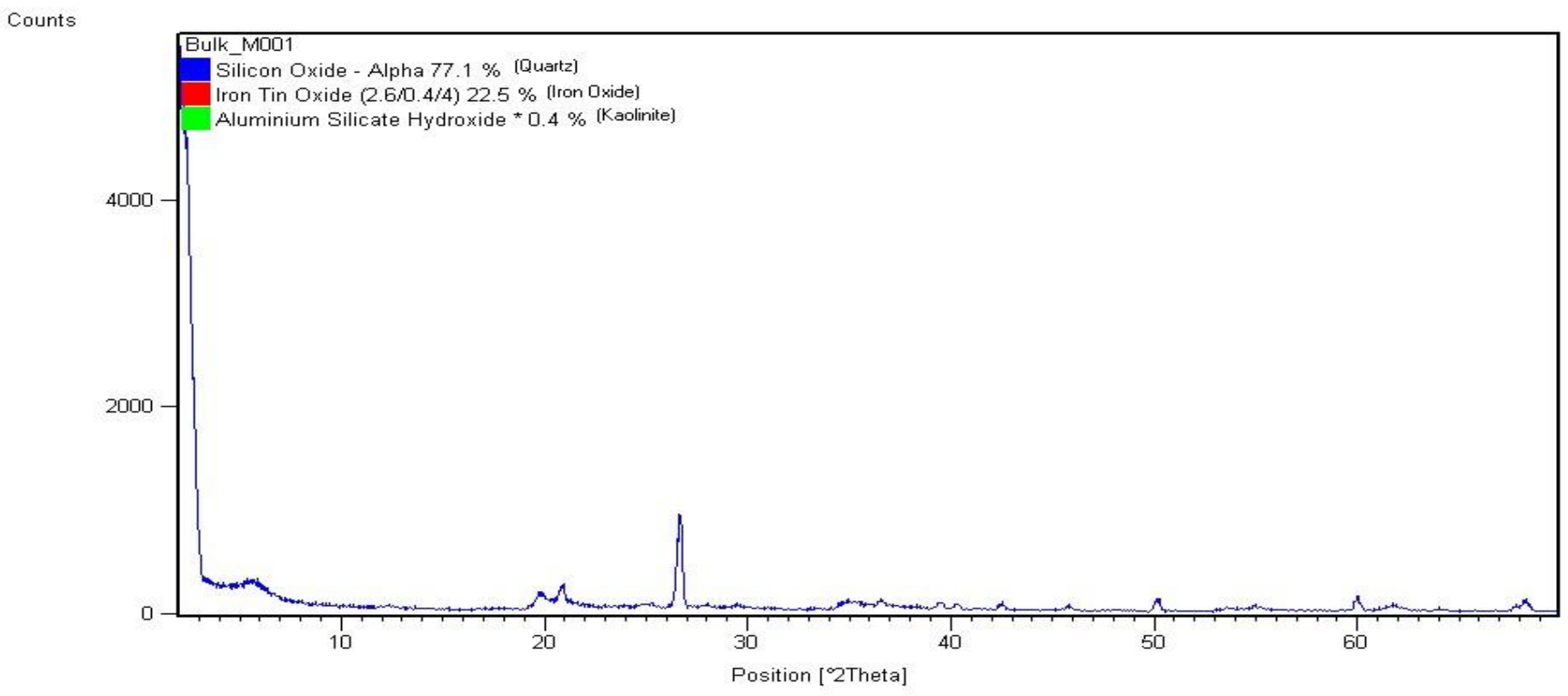


The clay minerals analysis by $\mathrm{X}$ - Ray diffraction pattern in profile (MG001) at the White Nile terrace indicated that the dominant clay type is smectite with percentage of 85.11 followed by kaolinite 11.5, chlorite 0.8 illite 1.25 and semectitelChrite 1.34 respectively (Table 4, Figure 20). The bulk minerals analysis indicates the presence quartz with percentage of 77.1 kaolinite; 0.4 and magnetite is also exist with percentage of 22.5. (Table 5, Figure 21).

In conclusion, this research study has been conducted to characterize and investigated the mineralogical properties of cracking clays at Middle and Lower clay plains of Eastern Nuba Mountains. Eight location sites were selected for this study; these sites were along a topographical sequence starting at the Middle clay plains (AlAbbasyiaand Terter area) and ending at Lower clay Plains (Megenis area) to compare the types of clay minerals in these plains. The results indicated that the Smectite was found to be the dominant clay minerals. Generally it ranges between (37.0, - $71.3 \%$ ), followed by the kaolinite, the clay mineral kaolinite was recorded in all of the investigated samples with variable percentages ranging between (22.2\% $46.45 \%)$. Therefore the presence of Kaolinite indicates accumulation of weathering product. Investigated soils also contain low amount chloride, illite and SmectitelChlorite.

The sequential weathering of the variable rock formation has led to the formation of the clay at different intermountain clay plains of the Nuba Mountains. It is anticipated that weathering in the western high lands areas at middle and lower plains occurred at variable intensities resulted in heterogeneous weathering product indicating that weathering of weatherable mineral was insufficient to the extent that remains of interlaying components have intervene and eventually interlayer the expandable layer silicates rendering it to take the characteristic of two minerals e.g. Montmorillonite and chloride.

The clay fraction of the bulk samples does not provide indication of smectitic clay minerals; the Al Abbasyia and Terter areas contain silicate minerals (mica, kaolinite and sodalite) and non-silicate minerals (clinochlore). As well these areas contain considerable amounts of Feldspars and Quartz. At the lower clay plains (Megenis) Albite and Kaolinite The quartz and magnetite are everywhere ubiquitous; this distributions pattern would indicate that Pedogenesis weathering of detrital minerals grains was rather extensive due to the action of excessive moisture regimes. White Nile deposits are characteristically dominated by Quartz and non-silicate (Magnetite). In aggregates this mineralogical assemblages occurring in Middle and Lower clay plains suggest origins of parent materials derived from basic igneous\metamorphic rocks that have under gone weathering and in situ formation of clay minerals that have imposed magnitude of variations in the Pedological features. The mineralogical analysis of White Nile sample reflect highest percent of Smectite and Magnetite and lowest percent of all associated minerals (Kaolinite, Illite and Chlorite) than all other site at Middle and lower clay plains indicating different processes of sorting of minerals compared to middle and lower clay plains.

\section{References}

Ahmed, N. 1996. Occurrence and distribution of Vertisols. In Ahmad, N., A. Mermut. (ed.). Vertisols and technologies for their management p.1-41. In Soil Science 24, Elsevier, Amsterdam, the Netherlands. 
Balwant, S. and H. Susan. 2002. Layer charge characteristics of Smectite from Vertisol of New South Wales. Australian J. Soil Res., 40(7): 1159 - 1170.

Caillaud, J.D.D., Proust, Righi, F., Martin. 2004. Fe-Rich Clays In A Weathering Profile Developed From Serpentinite Clay And Clay Minerals; v. 52; no. 6; p. 779791.

Chizhikova, N.P. 2005. Vertisols of Cuba: Mineralogical Composition and Response to Agrogenic Impacts (Plowing, Irrigation, and Fertilization) Eurasian Soil Sci., Vol. 38, No.10, pp. 1048-1057.

Dudal, R., H. Eswaran. 1988. Distribution Properties and Classification of the Vertisols In: Wilding L.P, Puentes R, editors. Vertisols: their distribution, properties, classification and management. College Station, Texas: Texas A\&M University Printing Center.

Grim, R.E. 1968. Clay mineralogy $2^{\text {nd }}$ ed. New York, M c: G raw-Hill, p.p. 596.

Mc Garry, D. 1996. The Structure and Grain Size Distribution of Vertisols, In: Vertisols and Technologies for Their Management (Eds.: N. Ahmad and A. Mermut). Developments on Soil Science.Vol. 24. Elsevier, Amsterdam, pp. 231-259. Kladivko E.J. (2001). Tillage Systems and Soil Ecology, Soil Tillage Res. 61, 61-76.

Moore, D.M, R.C. Jr Reynolds. 1989. X-ray Diffraction and the Identification and Analysis of Clay Minerals. Oxford, Oxford University Press, 332 pp.

Osman, R.A. 2006. Mineralogical Characterization of Some Soil Samples From East of Khartoum North (Sudan). Thesis Submitted In Partial Fulfilled Of the Requirement for the Degree of Master
Science, Faculty of Agricultural Sciences University of Gazira.

Pacheco and Dawoud, H.A. 1976. Exploratory, Soil Survey of North and South Kordofan Ministry of Agriculture Fisheries and Forestry. Soil Survey Administration Wad Medani, Sudan

Showgi, Omima, O.A. 2011. A study on properties and genesis ofcracking clay soils in Southern Kordofan, Sudan. Ph.D. Thesis (soil Science), Soil and Water Science Dept., College of Agricultural Studies. Sudan University of Science and Technology. Khartoum.

Showgi, Omima Omer, A., M. Ali, El-Abbas Doka, Dawoud, Hashim Ali and Mohamedain, Mahgoub Suliman. 2016. Mineralogical Properties of Cracking Clay Soils along Toposequence at Northern Upper Clay Plains of Nuba Mountains South Kordofan, Sudan. Int. J. Curr. Microbiol. App. Sci., 5(8): 745-759. doi:http://dx.doi.org/10.20546/ijcmas.201 6.508.084

Thorez, J. 1972. Practical Identification of Clay Minerals, First Edition G. Lelotte Dison Belgium.

Thorez, J. 1975. Phyllosilicates and Clay Minerals A Laboratory Handbook for Their X-Ray Diffraction Analysis Dison, Editions G. Lelotte, pp. 579

Tucker, M. (ed) 1988. Techniques in Sedimentology.Blackweel Scientific Publications California, .U .S .A.

Vail, J.R., D.C. Rex. 1971. Tectonic and Geochronological Studies in Sudan. $14^{\text {th }}$ annual Republic. Inst Afr. Geol. Univ Leeds, 44 47.

\section{How to cite this article:}

El-Abbas Doka M. Ali, Omima Omer A. Showgi, El Tag Fadlalla A. Rahim and Mahgoub Suliman Mohamedain. 2016. Mineralogical Properties of Cracking Clay Soils along Toposequence at Middle and Lower Clay Plains of Eastern Nuba Mountains South Kordofan, Sudan. Int.J.Curr.Microbiol.App.Sci. 5(10): 1049-1065. doi: http://dx.doi.org/10.20546/ijcmas.2016.510.111 